\title{
Gadget on Children Language Development
}

\author{
Erisa Kurniati ${ }^{1 *}$, Muhammad Zaim ${ }^{2}$, Jufrizal ${ }^{3}$, Jufri $^{4}$ \\ ${ }^{2,3,4}$ Universitas Batanghari Jambi, Indonesia ${ }^{1}$, Universitas Negeri Padang, Indonesia \\ *erisa.kurniati@unbari.ac.id
}

\begin{abstract}
The research is discussed about the concept of gadget, children language development, and the negative impact of gadget to children language development. This research is a theoretical study that examines theories related to gadgets and language development in children then describes the results in the form of narrative writing. The results showed that at this time, many children's toys already have high technology so that they can still make themselves cool even when they are alone. Plus if the child has busy parents, gadgets will usually be given to keep the child calm and absorbed in themselves for quite a long time. But apparently, this habit can bring bad effects to children's language development. The negative impacts include (1) Risk of radiation exposure, (2) Addiction, (3) Slow to understand the lesson, and, (4) The risk of abusing gadgets. The negative impact resulted in verbal interactions between children and parents and the surrounding areas became more and less neurological and this resulted in children's language skills not developing by their growth. Therefore parents need the supervision of the child when using a gadget, not even giving it if it is not under the child's developmental age.
\end{abstract}

Keywords: Gadget; Children Language Development.

\section{Introduction}

There are many factors between biology and experience related to language development [1]. We know about the culture that is important by determining the tools needed in life. Children develop language as they build other cognitive abilities by activating what they hear, looking for patterns, and setting rules.

The rapid development of technology affects increasingly striking lifestyles because technological developments affect the mass communication model to carry out daily life activities [2], [3]. Maybe once the internet was considered as a "wow" and complicated for ordinary people, but the fact now, as to what the internet has become common to many people. Today, we all know that technological progress is rapid; this progress certainly brings many changes to the culture in Indonesia.

It is undeniable that the advancement of information technology must indeed occur in the country of Indonesia so that the country of Indonesia is no less competitive with other countries. Today almost everyone has a gadget, and almost every day people are associated with gadgets.

Whether, it's for communication, work or business, it is looking for information or just for entertainment. Lately, parents are often found giving gadgets to their children. The role of 
parents who used to be playmates for their children has now been replaced by gadgets. Even though childhood is where the physical and psychological growth and development of humans, children must move a lot to develop children's optimal growth. If in childhood only cool in front of the gadget, the possibility of growth and development of children will be less than optimal both physically and psychologically children [3], [4].

It is noted that the development period of a sensitive child is 1-5 years. It is called The Golden Age. During this time all aspects of intellectual development, namely intellectual, emotional, and spiritual intelligence, experience extraordinary developments that will influence and determine future developments [6], [7], [8]. If the children have been given a toy in the form of a gadget at present, then it will affect the process of acquiring the language. Not to mention the audio coming out of these games, which sometimes emit sounds that might not have been heard by them. That these things can be recorded by children in their growth and development. This is because during this period it is usually marked by rapid changes in physical, cognitive, social, and emotional development [9].

Ironically, parents give gadgets to silence their children. Parents who are silence the children by giving a smartphone as well as parents who are lazy to educate children, because the smartphone's function shouldn't be that. They will understand that if you get bored or bored, there will be a smartphone that accompanies and becomes a toy in the form of games available on the smartphone so that it can change the mindset of children.

\section{Method}

This research is a theoretical study. The theories are collected, then analyzed and described in the form of narration. The steps in collecting data are collecting theories related to research problems, namely the theory of language development in children and its relation to using a gadget (android smartphone). Then analyze all related theories and describe them in the form of narrative writing.

\section{Result and Discussion}

\subsection{The Concept of Gadget}

The gadget is a term that comes from English, which means electronic devices that have special functions [3], [10]. In Indonesian, gadgets are referred to as "square". One of the things that distinguish gadgets from other electronic devices is the element of "novelty", meaning that from day to day gadgets always appear by presenting the latest technology that makes human life more practical.

Gadgets are one of the technologies that play an important role in this globalization era. Now, gadgets are no foreign objects, almost every society has them. Not only urban communities but gadgets are also owned by rural communities. Even gadgets do tend to be targeted at school-age children or teenagers [11].

They are now familiar with this technology. Various facilities and sophistication are easily offered by this one electronic device so that the public seems to be inevitably becoming hooked on this electronic device.

At first, the gadget was more focused on a communication tool, but since the progress of the age of this tool in advanced with a variety of features that are in it, allowing users to carry 
out various activities with this one gadget, ranging from phone calls, sending messages, emails, photos, hours and many others.

Apart from all, the gadget also has positive and negative impacts for anyone who enjoys it. Moreover, for children who have started using gadgets in their activities, negative and positive impacts will also occur [12]. Parents should be able to monitor their children in using the gadget properly so as not to cause negative impacts.

So the use of technological media such as gadgets needs to be restricted and supervised by parents when children use gadgets anywhere, and the average form of gadget use in children is only for playing games, and watching YouTube [4], [13].

\subsection{Children Language Development}

The process of language behavior is actually controlled by human cognition. So the aspects of stimulus and responses are not the sole factors of human language behavior. Watson seems to reduce the aspects of language behavior to the binary relationship of stimulus and response. Of course it is not a complete theory [14], [15], [16].

Moreover, Osgood [17] explains the process of semantic acquisition (meaning) is based on mediation theory or mediator. To him meaning is the result of one's learning process and experience and is a mediation to symbolize something. In short, meaning is a mediator and is a distinctive part of the overall response to an object in the word for that object, or the perception of the object.

This theory has better conceptual explanation that Watson's in the sense of not oversimplifying everything. In this theory, learning is influenced by behavior formed by its external environment through the conditioning of stimuli that give rise to a response. Osgood learns the truth about the nature of language in this theory although it lacks of explanation on more complex language behavior in social context.

All normal children can learn what languages are used by the surrounding community. When exiled from birth, this child does not acquire language. At this point nativistic approach is wrong to deny environmental influence. This kind of influence functions as external factors which are working reciprocally with human internal factors to master language. So both approaches, nativism and behaviorism, can be synthesized.

However, cognitive approach fails to explain the cognitive mechanism of language development. It is not only about reasoning process through learning. In fact, many Indonesian students learn English since early age at schools, but they cannot speak English fluently. They have no idea about how to use words in English. This fact alone proves some notions in cognitive approach are wrong, although other notions or concepts are true.

Language is an important part of life. The language of one individual with other individuals will be connected through the language process [1]. Language as a means of communication or communication between members of the community consisting of individuals who express their thoughts, feelings, and desires [18], [19], [20]. One of the language development disorders that can be caused by pressure from parents so that children speak clearly. Children's language development is in line with their biological development. It is used as a basis for why children at a certain age can already speak [21]. [22], [23], [24].

However, in their development, children generally have almost the same language acquisition components, both their phonological development, syntax, semantics, and pragmatics. This is certainly seen in terms of the normal language development of children. There are several components of child language development [25]:

1. Pragmatic Development 
Pragmatics is the study of recognizing the relationship between language and the context that is the basis of explanations regarding language understanding, in other words, pragmatic development in the context of children's language is an increase in the child's ability to say whatever he wants to say. Children's language development starts from the age of 7-12 years.

2. Sematic Development

Sematic development of children's language is a study of children's language skills that are associated with using what he expresses. Lexical and acquisition of concepts develop rapidly in pre-school. There are indications that children with more vocabulary eating are more popular with their peers. It is estimated that the addition of five words per day at the age of 1.5-6 years.

3. Syntactic Development

Syntactic development is the development of a child's ability to examine words in sentences and arrange each word to form a sentence. The earliest syntax is seen at about 18 months of age even though some children are seen at one year of age or even more than two. It can be summarized that language development is a very important part of life, with the language of one individual with other individuals will be connected through the language process.

Language development in children is the detection of symptoms that occur in children in the development process [21], [22]. By knowing the stages of children's language development teachers are expected to know the child's developmental needs and how to stimulate them according to the child's age.

In the development of language used to see the child's conversation accompanied by the use of technology to record children's voices. The following is an explanation of how to access child development. Stages of language development according to Ochs [23] are as follows:

1. Pre-talk level, age - 10 months, abilities are:

In the pre-speech level, children experience development in sound, cues, and the addition of sound perception, such as; baby talk which is the result of crying and commotion; playing with other people who begin at 3 months of age; between the ages of 6 (six) to 10 (ten) months can use limited consonants and vowels.

2. First words appearing names, ages 10 to 13 months, the abilities are:

At this age, children have been able to understand a single word, produce a single word, find out individual differences in the use of a single word, know the sign function as a word, and pay attention to directions by object names. At the age of 13 months, the child can receive vocabulary from 17 to 97 words.

3. Combination of words, age 18 to 24 months, its capabilities are:

At this age level, the child can use one single word with complex meanings for multi-word expressions, for example: "milk" (meaning it can ask for milk or ask for breast milk). The child has also been able to use a combination of words for sentences, for example: "mama drinks" (meaning mom asks for a drink).

\subsection{Impact of Gadgets on Children's Language Development}

The world of children is a world of the play, and language is a tool to communicate while they are playing [22], [30]. We can know that language development for children begins in infancy through language experience and growth. Communicating languages is a very important tool because without language someone will not be able to communicate with others. If communication between children is established, it is undeniable because of 
language. Children can express their thoughts through language so that others can capture what is thought by children [26]. Children who talk a lot sometimes become a reflection of an intelligent child.

Language development for children aims to enable children to communicate verbally with the surrounding environment [18]. The language skills are listening, speaking reading, and writing. So that adults can provide the stimulation the ability to listen, speak, read, and write so that the child's language development grows optimally according to his age.

Before the gadget was launched, people used a normal cellphone that was only used to make phone calls, send SMS, and use calculators with a variety of limited applications. Because the cost of calling by phone is relatively expensive, people switch communications via SMS. Similar to the telephone, SMS also incurs little by little to spend a lot of credit.

Along with the times, some gadgets are made to make it easier for users to communicate. The gadget is equipped with more complete applications including social media BBM, WA, Line, etc. which use subscription packages for a long period. The gadget is also equipped with a Wi-Fi network so that users can communicate for free.

Finally the gadget appears with the Android operating system that answers the needs of users. Apart from the sophistication of the gadget at this time, there are also many consequences [2], [25], [27], [8]. From young children to adults, all can use gadgets easily.

Here are some of the effects of using gadgets including:

a. Risk of radiation exposure

According to some studies, small children are more susceptible to radiation than adults. Gadgets not only cause harmful radiation, but the beam of light from the screen is very dangerous to children's health. They are still experiencing the development of the nervous system so it is very susceptible to radiation [4].

b. Addiction

As with adults, children are also at risk of addiction. At first, the children only play games but over time they have found their pleasure with these objects, causing children not interested in interacting with other people [28].

c. Slow to Understand the lesson

Habits of children who are engrossed in gadgets will affect the ability of the brain to get information. One of them is when children get lessons in school they have difficulty understanding what the teacher is saying. Besides, children tend to be lazy to learn and read, they prefer to play gadgets so that their performance decreases [29].

d. The Risk of abusing gadget

Today's parents must supervise their children when playing gadgets if it is not possible for children to access sites that should not, for example, pornography sites. This can make children go wrong, addicted and they will often do things that deviate [30].

\section{Conclusion}

Language development is an important part of life. The language of one individual with other individuals will be connected through the language process. Nowadays, children and technology cannot be separated from each other. They grow together as time goes on. One of the technologies that play an important role in this globalization era is the gadget. A gadget is a small object (tool or electronic item) that has a special function but is often associated as an innovation or new item. However, gadgets have a very big influence on language development in children, so in their use, it needs supervision from parents. 
Android-based gadgets are a major cause of children's language development not under the development of language at their age. This is because children are too cool to play with their gadgets so they don't communicate and socialize with parents or friends. Children's language development becomes inappropriate according to their age or under the development of their age.

\section{Acknowledgment}

In this ocassion, the researcher would like to say thank you to the Prof. M. Zaim, M.Hum, Prof. Jufrizal, M.Hum, and Dr. Jufri, M.Pd. who has guide the researcher from the begin until now. Without them, this research would not be able to do. Also motivated me to finish this research and write it on the article form. The researcher hopes, this research's result can be refere for the next researcher who will do the same topic's research.

\section{References}

[1] Kurniati, E. (2017). Perkembangan Bahasa Pada Anak dalam Psikologi Serta Implikasinya dalam Pembelajaran. Jurnal Ilmiah Universitas Batanghari Jambi, 17(3), 47-56.

[2] Chusna, P. A. (2017). Pengaruh Media Gadget Pada Perkembangan Karakter Anak. Dinamika Penelitian: Media Komunikasi Penelitian Sosial Keagamaan, 17(2), 315330.

[3] Maulida, H. (2013). Menelisik pengaruh penggunaan aplikasi gadget terhadap perkembangan psikologis anak usia dini. Jurnal Ilmiah Teknologi Pendidikan.

[4] Sari, T. P., \& Mitsalia, A. A. (2016). Pengaruh penggunaan gadget terhadap personal sosial anak usia pra sekolah di TKIT Al Mukmin. Profesi (Profesional Islam): Media Publikasi Penelitian, 13(2).

[5] Pebriana, P. H. (2017). Analisis penggunaan gadget terhadap kemampuan interaksi sosial pada anak usia dini. Jurnal Obsesi: Jurnal Pendidikan Anak Usia Dini, 1(1), $1-11$.

[6] Saputra, G. W., Rivai, M. A., Su’udah, M., Wulandari, S. L. G., Dewi, T. R., \& Fitroh, F. (2017). Pengaruh Teknologi Informasi Terhadap Kecerdasan (intelektual, spiritual, emosional dan sosial) studi kasus: anak-anak. STUDIA INFORMATIKA: JURNAL SISTEM INFORMASI, 10(2).

[7] Sundus, M. (2018). The impact of using gadgets on children. Journal of depression and anxiety, 7(1), 1-3.

[8] Sowmya, A. S. L., \& Manjuvani, E. (2019). Usage of electronic gadgets and language development of pre school children. International Journal of Home Science, 5 (2), 420-423.

[9] Widhianawati, N. (2011). Pengaruh pembelajaran gerak dan lagu dalam meningkatkan kecerdasan musikal dan kecerdasan kinestetik anak usia dini. Edisi Khusus, (2).

[10] Enwereuzor, I. K., Ugwu, L. I., \& Ugwu, D. I. (2016). Role of smartphone addiction in gambling passion and schoolwork engagement: a Dualistic Model of Passion approach. Asian journal of gambling issues and public health, 6(1), 9. 
[11] Nirwana, N., Mappapoleonro, A. M., \& Chairunnisa, C. (2018). The Effect of Gadget Toward Early Childhood Speaking Ability. Indonesian Journal of Early Childhood Education Studies, 7(2), 85-90.

[12] Al Sagr, A. N., \& Al Sagr, N. A. (2020). The effect of electronics on the growth and development of young children: A Narrative Review. Journal of Health Informatics in Developing Countries, 14(1).

[13] Delima, R., Arianti, N. K., \& Pramudyawardani, B. (2016). Pengembangan Aplikasi Permainan Edukasi Untuk Anak Prasekolh Menggunakan Pendekatan Child Centered Design. Duta Wacana Christian University.

[14] Piaget J. (2000). Psikologi Anak "The Psychology of the Child" (PenerjemahMiftahul Jannah). Yogyakarta: Pustaka Pelajar.

[15] Poedjiadi Anna. (1999). Pengantar Filsafat Ilmu Bagi Pendidik. Bandung: Yayasan Cendrawasih

[16] Kristiawan M\&Chandra R. (2016). Filsafat Pendidikan"The Choice is Yours". Yogyakarta: Valia Pustaka.

[17] Osgood, C.E. (1953). Method and Theory in Experimental Psychology. New York: Oxford.

[18] Shohamy, E. G. (2006). Language policy: Hidden agendas and new approaches. Psychology Press.

[19] Kyle, J. G., Kyle, J., Woll, B., Pullen, G., \& Maddix, F. (1988). Sign language: The study of deaf people and their language. Cambridge University Press.

[20] Ogden, C. K., \& Richards, I. A. (1923). The Meaning of Meaning: A Study of the Influence of Language upon Thought and of the Science of Symbolism. K. Paul, Trench, Trubner \& Company, Limited. (Vol. 29).

[21] McCarthy, D. (1933). Language development.

[22] Lovaas, O. I. (1977). The autistic child: Language development through behavior modification. Irvington.

[23] Ochs, E. (1988). Culture and language development: Language acquisition and language socialization in a Samoan village (No. 6). CUP Archive.

[24] Zubaidah, E. (2004). Perkembangan bahasa anak usia dini dan teknik pengembangan di sekolah. Cakrawala Pendidikan, (3), 87931.

[25] Sulistyawati, A. (2014). Deteksi tumbuh kembang anak. Jakarta: Salemba Medika.

[26] Dewi, Y. A. S. (2017). Korelasi Efektivitas Komunikasi dan Latar Belakang Etnis/Suku Orangtua Terhadap Perkembangan Bahasa Anak di Raudlatul Athfal Kabupaten Pasuruan. SELING: Jurnal Program Studi PGRA, 3(1).

[27] Novitasari, W., \& Khotimah, N. (2016). Dampak penggunaan gadget terhadap interksi sosial anak usia 5-6 tahun. PAUD Teratai, 5(3).

[28] Warisyah, Y. (2019, June). Pentingnya "pendampingan dialogis" orang tua dalam penggunaan gadget pada anak usia dini. In Seminar Nasional Pendidikan 2015 (pp. 130-138).

[29] Hastuti 2012.Psikolog Perkembangan Anak. Yogyakarta Tugu Publisher

[30] Andriana, D. (2011). Tumbuh kembang \& terapi bermain pada anak. Jakarta: Salemba Medika 